\title{
An Empirical Review on the Effects of ICT on the Humanist Thinking
}

\author{
Olivia Velarde Hermida*, Belén Casas-Mas*
}

* Complutense University of Madrid, Spain

Abstract

\begin{abstract}
The present article shows the results of a content analysis of scientific publications with two main goals - firstly, it is aimed at identifying the way the implications of ICT in dynamics that impact on the humanisation and dehumanisation of our societies are perceived in scientific publications. The second goal is to check if such representations provide continuity to the humanist thinking existing in the historical periods prior to the emergence of ICT. The content analysis is applied to the identification of narrative structure typologies with different arguments. A total of 136 different types of representations have been identified by applying the Systems Theory designed for the sampling of non-redundant systems. They are analysed with logical and structural methodologies that systemise the representations depending on whether they refer to socio-genetic or anthropo-genetic dynamics. The expected effects are identified, and it is verified that - in most cases - they will be considered both humanising and dehumanising. It is concluded that, as regards to the history of ideas, many humanist representations have continuity - they are still in force because they reflect persistent problems which remain unresolved; and there is a breakdown with the humanist thinking proposed by post-humanisms, which propose genetic and digital interventions that alter human nature.
\end{abstract}

Keywords: Humanisation; Dehumanisation; ICT Effects; Historic Changes; Digital Revolution; Posthumanism; Humanist Ideals.

Submitted: 13th June 2018

Accepted: 17th October 2018

\section{Introduction and objectives}

Humanisms, understood as the movements that orient social action to "the unfinished and unfinishable humanisation of society"1 (Martín Serrano, 2012), share the belief that humanity has the capacity and especially - the will to change itself. In order to fulfil this Promethean goal, human beings have created the tools that transform the nature of people and the state of societies, putting themselves at risk of perishing (Cf. Martín Serrano, 2007).

In many occasions, the conception and exercise of Humanism have been confronted to the social applications of technological innovations. Humanism and Techniques have participated in more or less compatible ways in historical changes that have reshaped human communities (Brockman, 2007).

In fact, since the middle of the $17^{\text {th }}$ century every time that a scientific-technical revolution has emerged in Europe, there have been thinkers who have analysed whether its consequences represented an effective progress or not for the society and the people of the time (see D'Alembert, 1751).

In our times - the so-called "time of globalisation" - Humanism faces another scientific-technical revolution - the digital revolution taking place in the field of information and communication (Chakrabarty, 2009). The social applications of such powerful technical resources will eventually and irreversibly transform the social organization and everyday life.

\footnotetext{
${ }^{1}$ Not to confuse "humanist thinking", which conceives humanization as a permanent project of human betterment, with the term "humanities", which refers to the set of disciplines related to art, languages and culture.
} 
It is necessary to stress the two sides that characterise the social uses of technologies and their advantages - uses that humanise us because they make us more creative and freer; and other uses that humanise us because they strengthen the control and power of certain individuals and groups over others (Molinuevo 2004).

With this background, a study has been designed and performed bearing in mind a prospective and a retrospective objective. These goals; which are historically, in the perspective of social changes, and theoretically, in the perspective of the transformation of ideas, related in the studies on humanisation / dehumanisation:

Prospectively: a content analysis has been conducted to identify a repertoire of representations that are described in the scientific publications. Such representations refer to the way in which social uses of ICT are producing irreversible effects in the organisation and functioning of societies; in particular, when these macro-sociological effects impact on humanisation or dehumanisation.

Retrospectively: it is checked the continuity or rupture between such current ideas, related to the humanising and dehumanising effects of ICT contained in scientific publications and the ideas inherited from the humanist thinking from other historical stages in which techniques and technologies have influenced macro-sociological changes because the analysis of the humanistic dimensions of ICT continues and updates a line of study existing since the first scientific-technical revolutions (Brockman, 2007).

The sources from which these retrospective data have been obtained are referenced in the context of the corresponding analyses.

In the present study, the changes generated by ICT with macro-sociological effects are taken into consideration. The texts that merely describe the impact of such technologies at a micro-sociological level are not relevant. For instance, there is extensive bibliography on the transformation of teaching since the advent of the Internet. Generally, these texts are not relevant, since they focus on the pedagogical use of these networks.

The publications considered in search of representations that may be part of the corpus of the study include texts in which the following references are related:

a) The emergence, use or application of any ICT

b) The incidence of a) over any change in societies or individuals.

c) The implication of a) and b) with historical advances or setbacks reflected in the humanising and dehumanising dynamics.

\section{Analysis / Methodology}

According to the objectives of this study, the universe of this research consists of all types of representations contained in scientific publications, the arguments of which are different among themselves and only for the representations that are different among themselves.

Thus, 136 different typologies have been identified - a number that represents quite a considerable repertoire considering the fact that they refer to certain specific macro-sociological transformations referred to humanization and dehumanization in this case. Since this is a typological study, each typology is included in the corpus once, as redundant representations are eliminated. Therefore, this figure is 
neither interpreted nor analysed as a statistical sample of the publications. In other words, this is not a quantitative study of the universe of scientific publications addressing these representation. This would be a subsequent study that is not intended now. This objective establishes the methodologies used in the research that supports this study (Cf. Velarde \& Bernete, 2016).

\section{The content analysis applied to the identification of representation typologies}

Typologies studies may be addressed in different manners. For instance, by means of qualitative techniques, when the representations are obtained from interviews with informants; or through analyses of narrative structures, when the information is obtained from texts, as in this case. The studies of typologies based on narrative structures represent a modality of content analysis that is structural by definition. As it is known, in order to establish the significance and validity of the results of structural studies, the criteria used in systems analyses are applied. (Cf. Martín Serrano, 2007). These systemic controls are different from the statistical significance and validity controls used when working with sets that do not operate as systems - such as representative random samples. In particular, we refer to completeness, which requires that the analysis units are structures - in this case, texts are analysed as complete arguments; correspondence, which requires that structures are identically formed - in this case, the representations contained in the texts are described following the same argumentative pattern; and, finally, the calculation of systems implementations, which is achieved when high redundancy levels are reached in the search of structures - in this case, representations typologies. (Cf. Martín, 2007, pp. 292296).

The techniques for the typological analysis of content include the logical analyses used and described below. Please find the reference at (Velarde \& Bernete, 2017). Among other recent studies based on the application of the same program of logical analysis, limiting the reference to the scope of this article, it is worth selecting the following on the grounds of the various range of topics addressed: (Franco, 2012; Ballesteros, 2012; Serrano, 2012; Bernete \& López, 2015; Cadilla, 2017; Casas-Mas, 2017).

\section{Drawing up the study corpus based on logical methodologies}

In scientific articles there might be relevant arguments expressed in a single paragraph or explained in several pages. Likewise, arguments may be articulated in a precise order or with no apparent order.

In order to save this narrative diversity in which the ideas we analyse are presented, they have been transcribed by using logical methodologies of content analysis. The texts describing any social change deriving from an ICT with impact in humanisation / dehumanisation were transcribed according to a logically structured single model. The arguments transcribed by means of this procedure faithfully respect the content - or sense - of the argument in its textual context, regardless of how it was expressed by its author. These arguments constitute the corpus of this study and follow the next structure:

$<$ There is a technology ( $T$ ) that is being applied in a specific form (F). As a consequence of this use there is an effect (E). The application of this technology ( $F$ of $T$ ) may influence in certain humanisation $(H)$ or dehumanisation (D) dynamics. > 
Arguments consist of propositions - or reasonings - that are interrelated by linguistic expressions acting as links². The following example was extracted from our corpus. Propositions are identified with its letter and each link is underlined:

"The Internet $(\mathrm{T})$ is used to connect people from different communities that did not have contact (F); this use fosters understanding between communities with different cultures (E); which will possibly lead humanity to see itself as one single global community $(H)^{\prime \prime}$.

In this way, it is possible to guarantee that the arguments that are part of the corpus include solely and exclusively the argumentation components. Besides, it is also guaranteed that arguments are described with the same narrative structure. As stated before, these requirements provide completeness and correspondence of the arguments, as requested by content systemic analyses.

\section{Sample selection}

As mentioned above, the criterion that defines the selection of a sample - which is used to identify typologies - is that all arguments registered are different from each other. But there are repeating arguments. The selection process is the following: when a text with arguments differing from the rest is identified, it is incorporated in the corpus. This means that, from that moment, the representations including the same argument and that may subsequently appear in other texts will not be included in the corpus. In order to avoid the selection of redundant entries, the "snowball search"3 system was used, which is applied as follows:

The arguments identified in the publications analysed were stored and encoded in a computer application that recognises if they are different or redundant with respect to the data saved. When the publication refers to previous publications in which issues related to the present study are addressed, these publications quoted in the text are also analysed and the new arguments obtained are also electronically registered. This process continues for as long as different arguments are obtained until we get into an endless loop of references. At this time, the analyses of the sources must be multiplied in order to obtain a new representations. In practice, redundancy increases rapidly. This is the time when the implementation of the representations systems may be assessed. In this study, the search was considered to be terminated when the likelihood of finding new representations was $4.5 \%$ with a confidence level of $95.5 \%$. By the time the search was concluded, up to 70 books, 10 book chapters and 33 scientific journal articles had been analysed. In total, 136 different arguments were recorded.

\section{Analysis results}

Let us make the following observation - the descriptions presented below are interpretations made by scientists on the humanist consequences the applications of ICT are having or may eventually have. They

\footnotetext{
${ }^{2}$ Klement (2010); Humberstone (2010); Badesa et al. (1998) are recommended for the application of concepts and the logical operations related to content analysis.

3 The "snowball" methodology is a structural analysis that operates with the inclusions and exclusions existing among elements in order to identify structural redundancies. These are logical models that may be used to generate typologies. Its foundations, logical programs and applications are described in (Martín Serrano, 1974).
} 
may or may not coincide with the effects that are already verifiable. Our intervention in this section consisted of systematically presenting all the arguments without introducing any value judgement.

The applications of ICT referring to the same humanising or dehumanising dynamics, are jointly grouped and analysed. For instance, several representations refer to the transfer or withdrawal of power to or from the civil society as a humanising or dehumanising dynamic. Some arguments present claim, selfmanagement and mobilisation capacities that, thanks to ICT, citizens and their social organisations have acquired; whereas other arguments highlight the power the digital revolution is conferring to Governments over citizens.

It is observed the relation of each dynamic with the previous humanist thinking, detecting continuities or ruptures with the authors that wondered about the role of technical advances in the development or involution of society and its members before the digital revolution, from the middle of the $17^{\text {th }}$ century. Whenever possible, the original works have been consulted.

During the analysis, it was noted that humanisation and dehumanisation dynamics may refer to changes in the state of societies or transformations in the nature of human beings. Therefore, this section is divided into two paragraphs: the first one on the role of ICT in the organisation and functioning of society since they affect the life conditions of people (that is to say, in the social genesis); and, the second one, on the role of ICT in the evolving characteristics of the human nature (that is to say, in the anthropogenesis).

\section{Humanisation and dehumanisation dynamics related to the effects of ICT in social genesis}

These dynamics were grouped in six categories as shown below:

- A fairer and more supportive society vs. a more unfair and unsupportive society

The new digital devices (T) used as communication media (F) bring to light realities that were hidden or remained unknown before, and that may promote justice and solidarity (E1). But they also transmit violent low-quality contents that promote gratuitous suffering, contempt or injustice (E2). These technologies may contribute, therefore, to make society more tolerant and sympathetic to others' suffering $(H) / /$ or more aggressive, insensitive or unsupportive (D).

According to the texts analysed, the presentation of collective misfortunes in networks triggers supportive responses and also endorsements to denounce unfair situations, which remained less known in the past. The capabilities of ICT to show historic breakthroughs that promotes sympathy and affection for others are underlined (for instance, the work of international organisations with the documentaries of the UNISDR - United Nations Officer for Disaster Risk Reduction).

However, other references point out that overexposing this type of content dulls the feeling of solidarity and "devalues suffering" (Chouliaraki, 2013). Trash TV is usually cited as examples. They exploit others' miseries, promote confrontation and spread scorn towards others (for instance, Sampedro, 2003).

The previous humanist thinking had already reflected on the importance of counteracting the irrational values that dehumanise. Since the appearance of L'Encyclopédie raisonée des Sciences et des Arts back in 1971, humanists ascribe the information and communication the ability to teach liberating knowledge and to set philanthropic human relations. Enlightened thinkers believed in the possibility and in the need 
to reorganise societies on the basis of "altruist principles" such as justice or kindness. According to Rousseau, such principles "are not merely abstract words, but are true affection of the soul enlightened by reason" (Rousseau, 1961, p.310).

It is mentioned that at this historical moment, digital media may make Humboldt's (1968, p. 284) ideal come true by linking "our inner self with the world (so) the concept "humanity" gains the richest possible content in us". However, despite the educational potential of ICT, there are concerns that the present digital revolution is not sufficiently contributing to the "spread of lights", that is to say, to promote knowledge based on "reason" and applied to "philanthropy".

- A more universal and tolerant society vs. a more individualist and intolerant society

Digital media and networks $(T)$ are used to access other cultures and to exchange cultural contents from different origins (F). All this may contribute to reorganise human links at a global level (E), whether it is achieved by inculcating more universal, respectful and open values $(H) / /$ or promoting the resurgence of individualist and intolerant attitudes and behaviours (D).

Dissanayake (2006) cites studies that confirm that the Internet promotes mutual understanding and respect. Davison (2017) examines the ways in which ICT contribute to social cohesion in Asian regions. It is believed that the cultural exchange on the Internet contributes to reorganise human links on universal values. Voelzqke and Rodrígues Ferreira (2015) draw attention on Paulo Freire's current work and his perspective of using technologies to humanise education. Foucault (1969) is often quoted when cultural exchange, universalist values and tolerance are linked. Furthermore, universal values may be inculcated in a manner compatible with the respect for other cultures and the effort to maintain them. ICT represent a set of tools to share cultural diversity in a globalised world, where even marginal societies may spread their values (Gurstein, 2007). In addition, the transnational cultural exchange may weaken the links between social organizations and their territories (for example, Lull, 2002), giving rise to a "planetary consciousness" (Archibugi, 2008) - an idea in line with The Global Village of McLuhan and Powers' (1989). However, other approaches consider that this cultural exchange will be insufficient to eliminate physical, political and mental boundaries, which may become more acute. Contrary to what was expected from globalisation and its technologies, nationalisms are on the rise (for example, Wolton, 1999). In fact, these dehumanising dynamics may end the cultural identity of many regions, since digital networks are the hugest transculturation system ever (Martín Serrano, 2004).

French utopians stated that the communications infrastructures would eliminate localism. For instance, Fourier (1845) predicted that the laying of submarine cables would transform the world into une organisation sociétaire. As stated by Foucault (1969), "the Sciences of Man" proposed by illuminists prevailed over the universal value of "human dignity". In scientific journals, it is still urged the need to use the power of media -nowadays digital media- to inculcate universal values. 
- Society with humanised economic development // with dehumanised economic development

The digital technological advances $(T)$ applied to the material production and reproduction of society (F) makes it possible to guide the society's economic functioning having a direct impact in the living conditions of population (E). This may lead to a dynamic in which the current economic organisation model is transformed and put to the service of man $(H)$ or a dynamic reproducing the economic model putting man at its service (D).

A line of reflections questions the current conditions of the capitalist economy and its sustainability. Supporters insist on the fact that digital technologies make it possible that the economic development remains subject to the achievement of previous social conditions (equal education opportunities, access to culture, etc.), in which the current conditions of neo-liberal economics may be questioned (for instance, Lin and Erickson 2008). Post-capitalism is announced (for instance, McChesney, 2014); although such criteria are not shared by many authors, such as Nnji (2014), who believes the implementation of these technologies is oriented to maintain an imperialist economic agenda as a characteristic of globalisation. Huysman and Wulf (2004) state that, in practice, socioeconomic and cultural divisions are deepening in an unprecedented era of scientific and technological development. More and more citizens feel such progress does not seem to lead to real improvement in the living and working conditions. They feel that those who live below the poverty threshold will not have access to the sharing happening on the network (Han, 2014). Thus, the digital divide widens the socio-economic and cultural gap, and both reinforce social division (McChesney, 1998).

It is repeatedly stated that ICT give access to knowledge and skills that allow individuals to educate themselves and "make themselves" (for instance Huysman and Wulf 2004) facilitating "empowerment". But new technologies do not always humanise work. Lukić (2014) states that employees experience an increasing feeling of loneliness and the loss of their identity at the workplace.

The observations according to which ICT contribute to dehumanisation rather than humanisation have increased in the past ten years. For instance, Marín-Casanova (2018) underlines that the impact of ICT has moved the traditional humanist contraposition from "cult / barbarian" to "cult / specialised". In the field of the humanist training of youngsters, Tao, Rozo and Barraza (2015) argue that "the education may not be abstracted from its mission of training individuals, who in addition to their cognitive and professional skills coexist in the global village and contribute to its integral development" (p.185).

These analyses on the role of ICT in redistributing the material resources and transformation of the economic functioning of society connects with the humanist thinking of the first capitalist industrial revolutions (pre-Fordists). In this time, the "Sociology" and the "Political economy" are developed as scientific fields focused on the transformation of the socioeconomic structures. Comte (1972a) states that "the principles" governing the use of technologies are not "moral" as illuminists believed, but "industrial". Comte (1912) noted that in societies rising from the industrial revolutions, humanisation and dehumanisation would emerge at the same time. The technological progress may improve the material conditions of humanity, but happiness is not among its objectives (Comte, 1972b). Marx (1867) considers that dehumanisation dynamics are due to laws operating during the industrialisation that must be historically questioned and overcome. For this author, the technical progress can be related to the improvement of the human condition, only if previously technical and social divisions disappear. 
- Society that transfers power from States to citizens // or increases State control over citizens

Global networks and new media (T) used as information, mobilisation and control instruments (F) are changing power relations between citizens and political organizations (E). ICT may contribute to establish citizen denouncement and control mechanisms over States $(H) / /$ or may promote the increase of State control over its citizens (D).

It is stated that global media transfer power to civil society and that virtual networks may promote global solidarity against interest groups (Leavitt, 2013). Communities will assume management functions (Kabra, 2007), which will their rights and freedoms. Many instances of citizen movements through social networks are described. They have overthrown regimes and changed electoral processes. They are usually considered as new ways of political participation (for instance, Sreberny, 2005). In short, it is stated that the Internet hampers the uncontrolled exercise of power and State impunity (for instance, Gergen, 2008). These analyses insist on the greater autonomy provided by mobile devices (for example, Castells et al. 2007). However, they also allow the localization of people at any moment and anywhere, which makes them very powerful control devices. For instance, the control of privacy may be applied to the global control of citizens by the existing powers (see Capurro et al., 2013). With ICT, the control exercised by political and economic organisations may be uncontrollable (Marsh et al., 2006). Some texts describe the use of ICT in "surveillance States" (for instance, Akrivopolou \& Psygkas, 2013). Government offices in charge of collecting and analysing information about people with unlawful purposes are mentioned. These practices are justified on the grounds of certain values - such as national security - that operate with emotions induced by fear (to terrorism, social unrest, etc.).

These dynamics are present since the $19^{\text {th }}$ century, in the figure of authors who aspire that control of power groups is transferred to civil society. Since the pre-Fordist industrialisation until now, the humanistic effects of this conflict confront "collectivist anarchism" against "scientific socialism", and social democracy against economic liberalism. Marxists and Bakunists have been discussing since 1872 the political role of parties and population movements.

- A more peaceful society with constructive relations // a more violent society with destructive relations

Electronic networks and media (T) are changing the forms of violence and the way they are managed (E); which may lead to new mechanisms of prevention, denouncement and education to hold more peaceful and constructive relations $(H)$ // or may derive in new forms of violence (virtual and symbolic) and in the increase of aggressions and destructive relations $(D)$.

Scientific publications report changes in the forms of violence and their management since the incorporation of ICT into everyday life. There are concerns for the "symbolic violence" - promoted by digital platforms. Discriminative "identification models" are established on the basis of gender (Stoleru \& Costescu, 2014), race or any other personal or collective feature (for example, Roosvall, 2014). According to Bordieu (2001), distances between dominant and dominated are pre-configured in discourses. This idea 
is supported by Miller (2014): there are "symbolic boundaries" in the net between "the cultural capitals" recognised for men and women.

The aggressive behaviours may be present in online platforms where aggressors may easily hide. Special attention is drawn to victims who are children or youngsters. In the virtual space, destructive and selfdestructive activities occur in new manners, such as the case of cyberbullying (Almeida, Correia, Marinho \& García, 2012; Quenta, 2015). Statistics from different countries reflect the growth of cyberbullying among schoolchildren since 2000; and it has been proven that this fact relates to the increase in the number and frequency of group contacts (Jones et al., 2013). Flechas (2013) does not share with other authors the idea that virtual classrooms imply greater quality in relations ("helping relationships, solidarity, empathy, respect, fraternity and dialogue") (Flechas, 2013, p.28).

There are also references in regard to the presentation of violence, which are preventive or palliative. Ybarra et al. (2008) present studies carried out in different countries that have found that since the year 2000, the exposure of children to violence, crime and abuse has increased on the Internet. However, although children are more exposed, their direct participation in these offences have decreased. This improvement may be related to the fact that ICT avoid social isolation (McPherson et al., 2008). Furthermore, they are suitable technologies to prevent behaviours through educational campaigns (Sim, 2017). These devices are also complaint channels that promote the prompt detection of violence cases, that give support and allow communication with victims, and that make easier the management of their recovery.

Lastly, it is worth mentioning the texts on institutional violence. Media manipulation is mentioned to raise uncertainties and collective fear, for example, for the purpose of legitimising military interventions (Scheper-Hughes \& Bourgeois, 2004).

Since the advent of audiovisual media - the violence inflicted through media has become one of the most commented topics in humanist thinking. Since the middle of the $20^{\text {th }}$ century, there are systematic studies on aggressiveness, the humiliation of the victims, and the contempt aggressors show for their victims (Adorno et al., 1950). Later, Gerbner (1986) analyses media manipulations that legitimate military interventionism. In particular, television presents the world as a hostile space that generates insecurity amongst the population, who finally seek protection in State apparatuses. From these sources, it was requested to use these media for the promotion of education, tolerance and solidarity. Scientific texts keep insisting on use of ICT, promoting critical thinking and peaceful behaviours; mainly because digital media have an extraordinary capacity to penetrate in the daily life of both victims and executioners.

- A society with autonomous and integrated individuals // a society with dependant and nonintegrated individuals

Electronic networks and new media are influencing the individual's development within societies, in shaping their identity and in integration mechanisms (E). This may help to conform healthy patterns and improve interpersonal relations $(H)$ or, on the contrary, may strengthen deviant behaviours in the social development of people - especially young people (D).

According to Northcole and Gosseline (2017), the virtual environments applied to online education provide greater flexibility and better access both for educators and students. The system itself contributes to a 
better adaptation to the digital environment by users. (Martínez-Barea, 2016). But, virtual networks are the environments in which the analysis on the contraposition between autonomy and dependence is generally placed. It is stated that they strengthen ties among youngsters, since they carry out tasks related to overcoming loneliness (for instance, Bonetti, Campblee \& Gilmore, 2010). Virtual groups control "social acceptance", which in these ages depends on the approval of other "peers", that is to say, other youngsters. Friendships managed through networks - totally or partially - are increasingly becoming more influential in the development of youngsters to the detriment of the role that family or school had played in the past (for example, Steinfield, Ellison \& Lampe, 2008).

Children can handle screens and other interactive devices from early stages of their intellectual and moral development. Those virtual experiences take the time and place of direct interactions with close relatives and other members of their peer group; which are the relations on which identities and values are based (Velarde, Bernete \& Franco, 2015). There is thus a risk noted by Riesman, Glazer and Denner back in 1961 - a society may be dehumanised when people's life is "directed by others".

Scientific publications mirror the influence of advertising and consumption through the Internet, which are becoming crucial elements in the construction of identities and offer "guidance schemes" to define individuals as "young" boys or girls, which refer to the consumption of articles (for instance, Royo, Miquel, Caplliure, 2006).

In fact, a "global marketing strategy" would be setting up in the virtual world, operating with all human values and available anywhere in our daily life thanks to mobile devices. Schulzke (2014) considers that the Internet transforms values into "imposed mirrors of consumption and work". Fromm's (1942) analyses are being recovered, which explained the advent of independent identities turning to "conformism" that promote massive communication and consumption. When digital technologies can serve as an open window to the world enriching individuals and helping them to reinforce their likes and identity, their consumption uses may derive into socioeconomic discriminations, existential frustration or maladjustment, among other pathologies. This concern has been present since the advent of massive communication media in works like "The Culture Industry" (Horkheimer \& Adorno, 1944).

\section{Humanisation and dehumanisation dynamics dealing with the effects of ICT in Anthropogenesis}

The arguments on the influence of ICT in the evolutionary features of human nature linked in the texts with humanisation and dehumanisation dynamics have been grouped in the two following parts:

- $\quad$ Full development of human intellectual capabilities // limited development of such capabilities

Digital technologies and communication networks $(T)$ have an impact on the satisfaction of immaterial needs (E). This may contribute to develop the intellectual capabilities of human beings, assisting in the collective building of knowledge $(H)$. But there is also a risk of regressive changes both to satisfy material needs and to develop intellectual changes (D). 
Digital networks promote interactivity and cooperative work among actors (Zacaré, 2018). Some publications understand that digital networks may channel the information required to satisfy the basic or material needs of human beings, making it possible to meet their non-material needs (Hilty, 2013). As Inglehart and Welzel (2005) points out, the resources available in times of abundance are destined for the personal and collective "fulfilment", rather than for the satisfaction of primary needs (adopting the socalled "post-materialist" values).

One of the most analysed matters in the texts is the role of ICT in the development of human intelligence and, in particular, in the collective production of knowledge. Individual intelligences incorporate their capabilities in networks for "the collaborative construction of knowledge" (Lévy, 1994). This possibility allows us to talk about Inglehart "connected" intelligence, which generates more accessible knowledge and more supportive uses (De Kerckhove, 1998). In fact, most of the current production of knowledge is already the work of teams where many human minds are implied (Wuchty, Benjamin \& Uzzi, 2007).

However, some works question these advances. It would be necessary to guide the new connected knowledge towards the basic well-being of human beings and not only to those economic and commercial applications of technology. It is reiterated that it is the people and not technologies who dehumanise through abusive use. Mariscal, Rivera and Larios (2017) warn that special attention must be paid to the generation following millennials, in order to foresee the consequences of the uses of time invested in ICT. This concern for the material and immaterial progress of humanity is still in force since the Enlightenment. The economic development and the satisfaction of basic needs allow the triggering of the creative potential of humanity. For instance, Kant defends "the desire to serve oneself from its own understanding" as the Enlightenment motto - "Sapere aude! Habe Mut, dich deines eigenen Verstandes zu bedienen! ist also der Wahlspruch der Aufklärung" (Kant, 1968, pp. 35-42). From the first authors of Enlightenment it was expected everyone participated in the production and exchange of knowledge whenever technology made it possible to initiate "the indefinite progress of the human spirit" (Condorcet, 1970). The digital revolution has been a time of promise in this sense, but scientific literature still reflects the existence of obstacles to achieve this ideal.

- A humankind that promotes its innate human capabilities // or that acquire "post-human" capabilities

Digital innovations (T) applied to the field of biology and artificial intelligence (F) are forcing the review of the division between what is natural and what is artificial, which may generate organic and functional transformations in the human body and brain (E). This may constitute an improvement of our capabilities, to which any human being may have access $(H)$. However, in the same way, it may lead to biological and behavioural alterations that put the future of the species at risk (D).

In the field of augmented reality, authors such as Tsaï (2016), consider that devices such as HMD increase users' sensorial options and thus promote communication among humans and between humans and nature.

The texts addressing the effects of the digital revolution in the human being describe organic transformations (Auletta, 2011) as well as "functional improvements" by incorporating digital components 
to the brain and to the rest of the body. These applications of ICT will improve the physical, psychological and intellectual capacities of people (for example, Bostrom, 2005; Braidotti, 2015).

These trends conceive ICT as an extension of human beings, in the future perspective in which the functioning of the body will be inseparably linked to its technological prostheses (for instance, Sandberg \& Bostrom, 2006; Savulescu \& Bostrom, 2009). These approaches propose to review the differences between "natural" and "artificial", including the conception of "human nature", to incorporate features of automation and artificial intelligence to the body; for example, the "Programme on the Impacts of Future Technology" jointly developed by the Faculty of Philosophy at Oxford University and the Oxford Martin School.

All in all, these texts are introducing a significant turn in the tradition of humanist thinking - they do not intend to attain the progress of humanity by changing the functioning of society or the behaviour and values of people, but by using technological manipulation of the evolutionary heritage. The intention to directly apply technologies to change human beings does not have historical precedents in other humanist ideas.

This transformation appears hand in hand with trends known as Transhumanism and Posthumanism that understand that in a near future hominization will be reopened for the technological control of human evolution (Kurzweil, 2012). The objective of "Transhumanists" is to create "a new man" "to guide human evolution" (Cf. American Humanist Association, 2003). Transhumanists consider themselves as representatives of enlightened humanism in the time of ICT (for instance, More, 2013). In addition, they are so when they do whatever it takes to promote the idea of using computer-communication tools to produce a new humanity (Braidotti. 2015). Even if such transformation destroys the difference between what is organic and what is manufactured. The International Humanist and Ethical Union (2002) states that transhumanism promotes the responsible use of resources and techniques to ensure human beings may fulfil themselves and be happy (Cortina, 2017).

At the same time, there are plenty of analyses on the ethical and socio-political implications of all these changes (for instance, Decker \& Guttmann, 2012; Torcal, 2018). It is feared that these interventions will threaten the future of humankind (for instance, Clark, 2010) and there is distrust towards the uses these technologies (Postigo, 2009). It is expected that when genetics is used to select the fittest, there will be inequalities between humans and post-humans (for instance, Kurzweil, 2005), with the risk that social Darwinism criteria may apply, including selective euthanasia.

\section{Conclusions}

The analysis carried out reveals three main conclusions:

- The first one is that most of the reflections about the role of ICT in humanisation or dehumanisation of our current societies and their members come from ideas prior to the digital revolution.

This is the expected conclusion since the values that underpin these reflections transcend eras. These conceptions have been built and rebuilt since the Enlightenment until the emergence of ICT and are still 
valid. This continuity allows the analysis of the interpretations that exist in scientific publications as the most recent stage in the development of humanist ideas, referred to the social applications of techniques.

Just in one out of the eight humanisation and dehumanisation dynamics identified in the texts a rupture with the previous humanist thinking is reported (corresponding to section 3.2.2.). It is considered that in order to achieve human progress, biotechnological changes must be performed on people's bodies. It is not possible to anticipate the long-term consequences of this intervention in the anthropogenesis, but the socio-ethical dimensions of these genetic manipulations are the most far-reaching ever faced by humanisms.

- The second conclusion is that the identified dynamics affecting social genesis and the first dynamic affecting anthropogenesis reflect the persistence of a concern or alarm due to unresolved problems.

The digital revolution provides resources to reach a higher social, economic and cultural progress. However, they do not seem to have resolved long-existing problems for the time being, and the solution of which does not only depend on technological advances (the extension of unsupportive and intolerant values and behaviours, the growth of economic inequalities, the increase of control over citizens, the advent of new forms of violence, or the problems of integration and acceptance of more and more people in their environment). In general, texts show a very critical attitude towards the uses made of these technologies, as well as hopelessness against their expected uses.

- The third conclusion is that there is a difference between the type of humanising reflections found in dynamics on social genesis and those found in dynamics on anthropogenesis.

When the social uses of ICT are related to socio-genetic transformations that influence humanisation / dehumanisation, most reflections are of palliative character - they seek to remedy pre-existing social problems or conflicts. By contrast, when the effects of ICT are related to the anthropogenesis, arguments are usually Promethean - they address the transformation of humanity into another species with superhuman capabilities. In fact, these programs proposing genetic and digital interventions that alter human nature believe humanism is cancelled and will be substituted by post-humanism. Humanists still point out that there are still problems that dehumanise, which are creating the existing differences between and within societies. In the texts analysed prevails the idea that post-humanism will increase such differences and will create other of genetic nature, which will be irreducible.

\section{Perspectives}

Socio-historical changes related to technological revolutions usually require several generations. Therefore, these are open processes. As all historical projections, the ones obtained from these publications also have scientific value since they are verifiable. We just need to wait until the time comes when such predictions are confirmed or denied. The present article provides a reference for those interested in this follow-up. 
The typological analysis described may also be used as a reference to design drafts or qualitative studies applied to scientists and academicians in the context of knowledge production and training; and to politicians and other leaders in the fields of governance and scientific and technological innovation.

\section{References}

Adorno, T.W., Aron, B., Hertzand, M., \& Morrow, W. (1950). The Authoritarian Personality, Studies in Prejudice. New York: Harper \& Row.

Akrivopoulou, C. \& Psygkas, A. Eds. (2013). Personal Data Privacy and Protection in a Surveillance Era: Technologies and Practices. Hershey: IGI Global.

Almeida, A., Correia, I., Marinho, S., \& Garcia, D. (2012). Virtual but not less real. In Le, Q., Cross, D., \& Smith, P.K. (Eds.), Cyberbullying in the global playground: Research from international perspectives (pp. 223-244). West Sussex: Willey-Blackwell.

American Humanist Association (2003). "Humanist Manifesto III". American Humanist Association. Available online at http://americanhumanist.org/Humanism/Humanist Manifesto III. Accessed on 02.06.2018.

Archibugi, D. (2008). The Global Commonwealth of Citizens: Toward Cosmopolitan Democracy. Vol. 6. Princeton: Princeton University Press.

Auletta, G. (2011). Cognitive biology: Dealing with information from bacteria to minds. Oxford: Oxford University Press.

Badesa, C., Jané, I. \& Jansana, R. (1998). Elementos de lógica formal. España: Editorial Ariel.

Ballesteros, B. (2012). Las tecnologías de la información y de la comunicación en los cambios laborales. Tesis doctoral. Madrid: Universidad Complutense de Madrid.

Bernete, F. \& Velarde, O. (2014). Designs for Social Sciences Study of Globalized Future Scenarios. International Journal of Humanities and Social Science, 4(11.1), 93-108.

Bernete, F. \& López-Navas, C. (2015). Transformaciones comunicativas que se relacionan con cambios educativos, cognitivos y existenciales. In Álvarez-Ruiz et al. (Coord.), Claves de la comunicación para niños y adolescentes (pp. 345-370). Madrid: Fragua.

Bonetti, L., Campbell M. A. \& Gilmore, L. (2010). The Relationship of Loneliness and Social Anxiety with Children's and Adolescents' Online Communication. Cyberpsychology, Behavior and Social Networking, $13(3), 279-85$.

Bordieu, P. (2001). Langage et Pouvoir Symbolique. Paris: Seuil.

Bostrom, N. (2005). Transhumanist Values. Review of Contemporary Philosophy, 4(1-2), 3-14.

Bostrom, Nick, dir. (n.d.) Oxford Martin Programme on the Impacts of Future Technology. Oxford: University of Oxford. Retrieved: http://www.oxfordmartin.ox.ac.uk/research/programmes/futuretech. Accessed on 02.06.2018.

Braidoti, R. (2015). Lo posthumano. Barcelona: Gedisa.

Brockman, J., Ed. (2007). El nuevo humanismo y las fronteras de la ciencia. Barcelona: Kairos.

Cadilla-Baz, M. (2017). Comportamientos de los estudiantes universitarios en Internet: La virtualización de actividades culturales y otras tareas cotidianas. In J. Rodríguez Terceño (coord.). Investigando en comunicación e investigando en docencia (pp. 49-64). Madrid: Tecnos. 
Casas-Mas, B. (2017). Transformaciones de la comunicación pública en la era de la globalización que influyeren en el consenso y el conflicto social. Tesis doctoral. Madrid: Universidad Complutense de Madrid.

Capurro, R., Eldred, M. \& Nagel, D. (2013). Digital Whoness: Identity, Privacy and Freedom in the Cyberworld. Frankfurt: OntosVerlag.

Marín-Casanova, J. A. (2018). La resemantización TIC de la cultura humanista. Index. Comunicación, 8 (1), 179-195.

Castells, M., Fernández-Ardèvol, M., Qiu, J. L., \& Sey, A. (2007). Mobile Communication and Society: $A$ Global Perspective. Cambridge MA: MIT Press.

Chakrabarty, D. (2009). Humanismo en la era de la globalización. Madrid/Buenos Aires: Katz editores.

Chouliaraki, L. (2013). The Ironic Spectator. Cambridge: Polity Press.

Clark, A.R. (2010). Transhumanism and Posthumanism: Lifting Man Up or Pulling Him Down?.Ignatius Insight. Available online at http://www.ignatiusinsight.com/features2010/aclark tranhumanism mar2010.asp Accessed on 02.06.2018.

Comte, A. (1912). Le système de politique positive. Paris: Georges Crès \& Cie.

Comte, A. (1972a). Considérations sur le pouvoir spiritual. In Tremblay, J.M, Opuscules de philosophie sociale (1819-1828). Availbale at: http://classiques.uqac.ca/classiques/Comte auguste/la science sociale extraits/1 opuscules phil o soc/opuscules philo sociale.pdf. (Original work published, 1826).

Comte, A. (1972b). "Séparation générale entre les opinions et les désir". In Tremblay, J.M, Opuscules de philosophie sociale (1819-1828). Availbale at: http://classiques.uqac.ca/classiques/Comte auguste/la science sociale extraits/1 opuscules phil o soc/opuscules philo sociale.pdf. (Original work published, 1819).

Condorcet, N. (1970). Esquisse d'un tableau historique des progrès de l'esprit humain. Paris: Librairie philosophique J. Vrin.

Cortina, A. (2017). Humansimo avanzado para una sociedad biotecnológica. Madrid: Ediciones Teconté.

D’Alembert, J.R. (1751). "Discours préliminaire des éditeurs". In D’Alembert, J.R. \& Diderot, D. (Dirs.) Encyclopédie ou dictionnaire raisonné des sciences, des arts et des metiers. Tome 1. Available online at https://encyclopedie.uchicago.edu/node/88. Accessed on 02.06.2018.

Davison, R.M. (2017). "Facilitating social harmony through ICTs". In Choudrie, J., Islam, M.S., Wahid, F., Bass, J.M., Priyatma, J.E. (Eds.), Information and Communication Technologies for Development (pp. 3-9). Switzerland: Springer International Publishing.

Decker, M. \& Gutmann, M. Eds. (2012). Robo-and Informationethics: Some Fundamentals. Berlin: LIT.

De Kerckhove, D. (1998). Connectedintelligence: Thearrival of the Web Society. London: Kogan Page.

Dissanayake, W. (2006). "Globalization and the Experience of Culture: The Resilience of Nationhood". In Gentz, N, \& Kramer, S. (Eds.), Globalization, Cultural Identities, and Media Representations (pp. 25-44). New York: State University of New York Press Albany.

Flechas, N. (2013). "El Ciber Bullying en la Educación Virtual: Propuesta de una Ciber Ética Prosocial". In Gamboa, A. \& Avendaño, D. (Comp.) Compilación Estado del Arte. Proyecto Alfa-Spring (pp. 2637). Chile: Pontificia Universidad Católica de Valparaíso.

Foucault, M. (1969). L'archéologie du savoir. Paris: Gallimard. 
Fourier, C. (1845). Le nouveau monde industriel et sociétaire ou invention du procédé d'industrie attrayante et naturelle distribuée en series passionnées. Paris: Librairie sociétaire.

Franco, D. (2012). La transferencia de los desajustes sociales a los sujetos individuales: un análisis desde la mediación social. Tesis doctoral. Madrid: Universidad Complutense de Madrid.

Fromm, E. (1942). The Fear of Freedom. London: Routledge and Kegan Paul.

Gerbner, G., Gross, L. Morgan, M. \& Signorielli, N. (1986). "Living with Television: The Dynamics of the Cultivation Process". In Bryant, J. \& Zillmann, D. (Eds.), Perspectives on Media Effects. (pp.1740). New Jersey: Lawrence Erlbaum Associates.

Gergen, K.J. (2008). "Mobile Communication and the Transformation of the Democratic Process". In Katz, J.E. (Ed.), Handbook of Mobile Communication Studies. (pp. 297-310). Cambridge: MIT Press.

Gurstein, M. (2007). What Is Community Informatics (and Why Does It Matter)? Vol. 2. Milan: Polimetricasas.

Han, B. C. (2014). En el enjambre. (R. Gabás, trad.). Barcelona: Herder.

Hilty, M. (2013). "How to Improve the Contribution of ICT to Sustainability". In Hilty, L. M., Aebischer, B., Andersson, G. \& Lohmann, W. (Eds.) International Conference on Information and Communication Technologies for Sustainability (pp. 283-287). Zurich: University of Zurich.

Horkheimer, M. \& Adorno, T.W. (1944). "The Culture Industry: Enlightenment as Mass Deception". In Dialectic of Enlightenment. New York: Social Studies Assoc.

Humberstone, L. (2010). "Sentence Connectives in Formal Logic". In Zalta, E.N. Ed., The Stanford Encyclopedia of Philosophy. Stanford: Stanford University.

Humboldt, W. (1968). Gesammelte schriften. Berlin: De Gruyter.

Huysman, M. \& Wulf, V. (2004). Social capital and information technology: Current debates and research. Cambridge: MIT Press.

Inglehart, R. y Welzel, C. (2005). Modernization, Cultural Change, and Democracy: The Human Development Sequence. Cambridge: University Press.

Jones, L. M., Kimberly J. M., \& Finkelhor, D. (2013). Online Harassment in Context: Trends from Three Youth Internet Safety Surveys. (2000, 2005, 2010). Psychology of Violence, 3 (1) 53-69.

Kabra, K. N. (2007). "Globalization and the Changing Role of the State: Issues \& Impact". IASSI Quarterly 26(2), 147-51.

Kant, I. (1968). "Was ist Aufklärung?". In Werke, K.Akademie-textausgabe. Vol. VIII. Berlin: Walter de Gruyter.

Klement, K.C. (2010). "Propositional Logic". In Fieser, F. \& Dowden, B. Eds. Internet Encyclopedia of Philosophy. Available online at http://www.iep.utm.edu/prop-log/. Accessed on 02.06.2018.

KurZweil, R. (2012). La Singularidad está cerca. Cuando los humanos transcendamos la biología. Berlín: Lola Books.

Leavitt, L. (2013). Institutional memory and ICT: Ingredients for direct democracy and global solidarity. International Journal of Information Communication Technologies and Human Development (IJICTHD), 5 (3), 41-63.

Lévy, P. (1997). L'intelligence collective: Pour uneanthropologie du cyberespace. Paris: La Découverte.

Lin, N., \& Erickson, B.H. (2008). "Theory, Measurement, and the Research Enterprise on Social Capital". In Nan L., \& Erickson, B.H. (Eds.), Social Capital: An International Research Program (pp. 1-24). Oxford: Oxford University Press. 
Lukić, J. (2014). The role of information and communication technology in a virtual organization. Challenges for virtual employees. En AA. VV.1st International Academic Conference Places and Technologies (pp. 1098-1105). Belgrade: University of Belgrade.

Lull, J. (2002). "Superkultur". In Löffelholz, M., \& Hepp, A. (Eds.), Grundlagentexte zur transkulturellen Kommunikation. (pp. 750-773). Konstanz: UVK.

Long, C. (2014). Discourse Monopoly: The Communication Practice of Online Populism. Cross-Cultural Communication, $10(1), 7-12$.

Mariscal, M., Rivera, A. \& Larios, E. (2007). La des-humanización de la generación millennial por la influencia de la tecnología. Jóvenes en la ciencia, 2 (1), 712-715.

Marsh, D., Smith, N. J., \& Hothi, N. (2006). "Globalization and the State". In Day, C., Lister, M., \& Marsh, D. (Eds.), The state. Theories and Issues (pp.172-190). New Hampshire (US): PoliticalAnalysis.

Martín Serrano, M. (1974) Nuevos métodos para la investigación de la estructura y la dinámica de la enculturización. Revista Española de Investigaciones Sociológicas (REIS), 37, 23-83.

Martín Serrano, M. (2004). Orígenes históricos de los usos actuales de la comunicación pública. Diálogos De La Comunicación, 69, 98-108.

Martín Serrano, M. (2007). Teoría de la Comunicación. La comunicación la vida y la sociedad. Madrid: McGraw- Hill.

Martín Serrano, M. (2012). De la libertad para hacer ciencia y de la ciencia para la libertad, Multidisciplina, $13,84-95$.

Martínez-Barea, J. (2016). El mundo que viene. Descubre por qué las próximas décadas serán las más apasionantes de la historia de la humanidad. Barcelona: Planeta.

Marx, K. (1867). "Maschinerie und große Industrie". In Karl, M. Das Kapital. Bd. I. (pp. 483-530). Berlin: Dietz Verlag.

McChesney, R. W. (Ed.). (1998). Capitalism and the Information Age: The Political Economy of the Global Communication Revolution. New York: Monthly Review.

McChesney, R. W. (2014). Blowing the Roof Off the Twenty-first Century: Media, Politics, and the Struggle for Post-capitalist Democracy. New York: Monthly Review Press.

McLuhan, M, \& Powers, B.R. (1989). The Global Village: Transformations in World Life and Media in the 21st Century. Oxford: Oxford University Press.

McPherson, M., Smith-Lovin, L., \& Brashears, M. E. (2008). Social Isolation in America: Changes in Core Discussion Networks over Two Decades. American Sociological Review, 73, (6), 1022-1022.

Miller, D. L. (2014). Symbolic Capital and Gender: Evidence from Two Cultural Fields. Cultural Sociology, 8 (4), 462-82.

Molinuevo, J. L. (2004). Humanismo y nuevas tecnologías. Madrid: Alianza Editorial.

More, M. (2013). The Philosophy of Transhumanism. Oxford: John Wiley \& Sons.

Naam, R. (2005). More Than Human: Embracing the Promise of Biological Enhancement, Ebook. New York: Broadway Books.

Nneji, B. U. (2014). Technologies in Education and the Dehumanization and Imperialization of Pedagogy: The African Perspective. Bulgarian Journal of Science and Education Policy, 8(1), 86-105.

Northcote, M., \& Gosselin, K. P. (Eds.). (2017). Handbook of Research on Humanizing the Distance Learning Experience. Hershey: IGI Global. 
Postigo, E. (2009). Transumanesimo e postumano: principi teorici e implicazioni bioetiche. Medicina $e$ Morale, 2, 267-282.

Quenta, L. (2015). Bullying escolar e ideación suicida en los estudiantes del tercer año de secundaria de instituciones educativas públicas, Tacna, 2015. Master's Degree Thesis. Perú: Universidad Peruana Unión.

Riesman, D., Glazer, N., \& Denney, R. (1961). The Lonely Crowd. Yale: University Press.

Roosvall, A. (2014). The Identity Politics of World News: Oneness, Particularity, Identity and Status in Online Slideshows. International Journal of Cultural Studies, 17 (1), 55-74.

Rousseau, J. J. (1961). Émile ou de l'éducation. Paris: Garnier.

Royo, M., Miquel, M.J., \& Caplliure, E. (2006). Advertising content as a socialization agent: Potential reinforcement of gender stereotypes. EsicMarket, 125, 81-134.

Sampedro, V. (2003). "La McTele como industria de identidades lucrativas y de consumo. Análisis de Gran Hermano y Operación Triunfo". In Sampedro, V. (Ed.), La pantalla de las identidades: Medios de comunicación, políticas y mercados de identidad. (pp. 305-335). Barcelona: Icaria.

Sandberg, A., \& Bostrom, B. (2006). Converging Cognitive Enhancements. Annals of the New York Academy of Sciences, 1093 (1), 201-227.

Savulescu, J., \& Bostrom, N. (Eds.). (2009). Human enhancement. Oxford: Oxford University Press.

Scheper-Hughes, N., \& Bourgois, P.I. (2004). Violence in War and Peace: An Anthology. Malden: Blackwell Publishing.

Schienstock, G. (Coord.) (2002). "Information Society, Work and the Generation of New Forms of Social Exclusion (SOWING). Final Report". Project funded by the European Community under the Targeted Socio-Economic Research Programme (TSER). Available online at http://www.uta.fi/laitokset/tyoelama/sowing/report/SowingFinal2002.pdf. Accessed on 02.06.2018.

Schulzke, M. (2014). The Virtual Culture Industry: Work and Play in Virtual Worlds. The Information Society, $30(1), 20-30$.

Serrano, R. (2012). La aflicción de la docencia y el tiempo del enseñante. Razón y Palabra, 1779).

Sim, K.N. (2017). "Researching Distance Education: A Possibility to Humanize It". In Northcote, M., \& Gosselin, K. P. (Eds.). Handbook of Research on Humanizing the Distance Learning Experience. (pp. 26-47). Hershey: IGI Global.

Sreberny, A. (2005). "Globalization, Communication, Democratization: Toward Gender Equality". In Hackett, R.A., \& Zhao, Y. (Eds.), Democratizing Global Media: One World Many Struggles (pp. 245-267. Lanham, Maryland: Rowman \& Littlefield Publishers.

Steinfield, C., Ellison, N.B. \& Lampe, C. (2008). Social Capital, Self-esteem, and Use of Online Social Network Sites: A Longitudinal Analysis. Journal of Applied Developmental Psychology, 29(6), 434445.

Stoleru, M., \& Costescu, E. (2014). (Re)Producing Violence against Women in Online Spaces. Philobiblon, 19(1), 95-114.

Tao, H. B., Rozo, O. P., \& Barraza, J. M. S. (2015). Educación y ágora digital: retos y horizontes para la formación humanística. Agora USB, 15(1), 169-193.

Torcal, L. (2018). Integración versus superación. El corazón del problema tecnoético. Telos, 109, 188-199.

Tsaï, F. (2016). Virtual Reality, a Tool to Reconnect with Sensoriality?. Hermès, La Revue, (1), 188-199. 
Velarde, O., Bernete, F., \& Franco, D. (2015). Paradigmas de los efectos de las TIC en la cultura y en el conocimiento. Revista Latina de Comunicación Social, 70, 347-80.

Velarde, O., \& Bernete, F. (2016). "Transformaciones de la comunicación vinculadas a las TIC. Métodos de investigación", In Martínez, E., Raya, P., \& Martínez, X. (coord.): Investigación, desarrollo e innovación universitarios (pp. 755-768). Madrid: McGraw Hill.

Velarde, O., \& Bernete, F. (2017). "Diseños para analizar las representaciones de la comunicación en la era de la globalización", en García, A. (coord.): Aportaciones de vanguardia en la investigación actual. (pp. 57-72) Madrid: Tecnos.

Voelzke, M., \& Rodrigues Ferreira, O. (2015). Distance education: the humanization of technology. IAU General Assembly, 22.

Wolton, D. (1999). Internet et après?: Une théorie critique des nouveauxmédias. Paris: Flammarion.

Wuchty, S., Benjamin F. J., \& Uzzi, B. (2007). The Increasing Dominance of Teams in Production of Knowledge. Science, 316 (5827), 1036-1039.

Ybarra, M. L., Diener-West, M. Markow, D., Leaf, P.J., Hamburger, M., \& Boxer, P. (2008). Linkages Between Internet and Other Media Violence with Seriously Violent Behavior by Youth. Pediatrics, 122 (5), 929-37.

Zacarés, A. (2018). La filosofía en los tiempos del cyborg y de la posverdad. I Jornades de Filosofía a Secundario. Valencia: Cefire. Humanistic i Social. 